\title{
Study of Some Headed Chinese Cabbage Varieties and Hybrids Growth and Development in Autumn Open Field Culture in Transylvanian Tableland Specific Conditions
}

\author{
Enikő LACZI*), Alexandru APAHIDEAN, Emil LUCA, Adelina DUMITRAȘ \\ University of Agricultural Sciences and Veterinary Medicine Cluj-Napoca, Faculty of Horticulture, \\ Calea Mănăștur 3-5, 400372, Cluj-Napoca, Cluj, Romania; \\ ${ }^{*}$ Corresponding author, e-mail: eniko.laczi@yahoo.com
}

Bulletin UASVM Horticulture 72(1) / 2015

Print ISSN 1843-5254, Electronic ISSN 1843-5394

Doi:10.15835/buasvmcn-hort:10347

\begin{abstract}
Chinese cabbage is a leafy vegetable often cultivated in Asia, but which has also become more and more known in Romania due to its high nutritional value. The main purpose of this experiment was to study the behavior of some Chinese cabbage varieties in the Transylvanian Tableland specific conditions in an autumn open field culture, being known that there is no adequate cultivation technology for this vegetable for this region, vegetable producers having difficulties in special because of the bolting and inappropriate cultivar choose. To achieve the objectives of this experiment a collection of 5 varieties and hybrids was organized. During growing season observations were made regarding plants growth and development, at harvest on the yield quality and quantity, a high importance being given to the number of bolted plants. Plants head weight varied between $0.77 \mathrm{~kg}$ and $0.99 \mathrm{~kg}$, while the cabbage heads had weights between $0.57 \mathrm{~kg}$ and $0.86 \mathrm{~kg}$. At harvest only one hybrid presented a minimum bolting percentage, while to another one the percentage passed $40 \%$. The yields obtained within this experiment varied between 45.3 and $67.2 \mathrm{t} / \mathrm{ha}$. The success of the Chinese cabbage crop is in direct relationship with choosing a good hybrid, which is bolting resistant and can give a high yield.
\end{abstract}

Keywords: autumn culture, Chinese cabbage, leafy vegetable, high yield.

\section{INTRODUCTION}

Chinese cabbage (Brassica campestris var. pekinensis) is a popular vegetable with many benefits for both, growers and consumers: for growers is the short cultivation period, while for the consumers its high nutritional quality (Larkcom, 2008). Due to its good taste and high nutritional value the request for this vegetable is higher and higher (Larkcom, 2003). Its content of dry matter is around $5 \%$, dietary fibre $10 \mathrm{~g} / \mathrm{kg}$, potassium 2.5 $\mathrm{mg} / \mathrm{kg}$, calcium $1.05 \mathrm{mg} / \mathrm{kg}$, magnesium $190 \mathrm{mg} /$ $\mathrm{kg}$, sodium $650 \mathrm{mg} / \mathrm{kg}$ (Pokluda, 2008). Studies have shown that the calcium content can be even higher, reaching a value of $330 \mathrm{mg} / \mathrm{kg}$ (Kawashima and Valentesolares, 2003). An other benefit for the growers consists in the high yield which can be obtained under good cultivation technique. The yields of headed Chinese cabbage varies between 30 to $50 \mathrm{t} /$ ha (Toxopeus and Baas, 2004) or even between 40 to 100 t/ha (Chaux and Foury, 1994). Earlier studies showed that more varieties and hybrids of Chinese cabbage (Granat and Vitimo $F_{1}$ ) can be grown successfully either in spring or fall in Transylvania Tableland specific conditions (Laczi et al., 2013; Laczi et al., 2014), but early planting is crucial to achieve an early yield and consequently a high price (Kalisz and Cebula, 2006). Due to the fact that Chinese cabbage was not cultivated or studied sufficiently in Romania, in special in Transylvanian Tableland, the present research cames with new informations about the cultivation technology of this vegetable. The main 
aim of this experiment was to study the behavior of five Chinese cabbage varieties in the pedoclimatic conditions of this region, in an autumn open field culture.

The present research is a part of a larger study which had the role to establish if some varieties of Chinese cabbage can be cultivated in Transylvanian Tableland specific conditions and when is the perfect moment to establish a crop, being given the fact that this vegetable has a high tendency to bolt, if it doesn't find favorable agropedo-climatic conditions. The study involved several varieties and hybrids (some of them were cultivated already in this area, other ones were purchased from different seed producers from abroad) which were cultivated in several places and periods of the year (the crops were established in polyethylene tunnel in spring and autumn, while in open field the planting was made three times, to obtain an early and a late spring crop, and in summer to obtain an autumn crop). Partial results of this experiment were published by Laczi and Apahidean (2011, 2012), Laczi et al. $(2013,2014 \mathrm{a})$ and presented in conferences (Laczi et al., 2014b). The main results of the research underlines the fact that Chinese cabbage can be grown with success in this region, but there is necessary an appropriate cultivation technology and more studies regarding the existing cultivars on the market, in order to reduce the bolting ratio. This paper demonstrates the effectiveness of autumn crops, in relation with decreasing the number of bolted plants and increasing the yield.

\section{MATERIALS AND METHODS}

The research took place in the experimental field belonging to the Vegetable Growing Department from the University of Agricultural Sciences and Veterinary Medicine Cluj - Napoca, in the autumn of 2011, the experiment taking place from July to November. By position, the experimental site falls into the moderate continental climate which is characteristic of western and north western region of the country (Morariu and Savu, 1970).

The main purpose of this experiment was to study the behavior of some Chinese cabbage varieties in the Transylvanian Tableland specific conditions in an autumn open field culture. To achieve the objectives of this experiment a collection of varieties and hybrids was organized, which involved the following varieties: Michihli, Kingdom 80, Granat, Nepa $\mathrm{F}_{1}$ and Vitimo $\mathrm{F}_{1}$

Some of these varieties were studied earlier (Laczi and Apahidean, 2012), but in protected cultures. Several studies (Laczi et al., 2013; Laczi et al., 2014) revealed that the behavior of this vegetable, in this region, is different when planting is made in open field or the crop is in polyethylene tunnel, the main difference being given in special by the quality of the yield and the number of bolted plants. Seeds of hybrid Vitimo $\mathrm{F}_{1}$ and variety Granat can be found in Romanian markets, while hybrids Michihli, Kingdom 80 and Nepa $F_{1}$ were purchased from abroad (USA) and introduced in the research to test their behavior and yield results in our region.

Each variety was placed into three repetitions. Seeds were sown in $20^{\text {th }}$ of July, one by one, in small nutrient pots and were transplanted in bigger pots in stage of 3-4 true leaves, in $8^{\text {th }}$ of August. Planting was made after 12 days, in $20^{\text {th }}$ of August in open field.

During the vegetation period, no treatments nor fertilizations were necessary. Harvest started in $20^{\text {th }}$ of September (at Granat variety and Nepa $\mathrm{F}_{1}$ and Michihli hybrids) and ended in $25^{\text {th }}$ of November, being harvested cabbage heads which reached the specific weight of the variety. During growing season observations were made regarding plants growth and development, at harvest on the yield quality and quantity, a high importance being given to the number of bolted plants. Before planting seedlings height and diameter was measured, the leaves were numbered and the weight was noted. One month after planting the first three measurements were repeated, and the number of bolted plants was registered. Before harvest, plants height and diameter was measured, after that plants were cut and weighed. The outer leaves were numbered removed to obtain the marketable cabbage heads, which were also measured from height and diameter point of view, were weighed and the leaves were numbered. The number of bolted plants was again noted in order to calculate the bolting percentage. The quality of cabbage heads was established taking into consideration the standards presented by "The African Organization for Standardisation" (2012). 


\section{RESULTS AND DISCUSSIONS}

At planting hybrid Michihli had the highest height $(27.3 \mathrm{~cm})$, while hybrid Vitimo $\mathrm{F}_{1}$ registered the highest plant diameter $(26.0 \mathrm{~cm})$ and lowest weigh $(14.0 \mathrm{~g})$. Seedlings of hybrid Nepa $\mathrm{F}_{1}$ had the highest weight $(17.7 \mathrm{~g})$ and the highest number of leaves (7.7 leaves) (tab. 1). Close results were found in a study made in protected area, where the average seedlings height and diameter were lower (Laczi et al., 2014). Compared to the spring crops, seedlings had higher values of al measured characters, which is due to the better climatic conditions. Therefore the average height of plants was higher with approximately $10 \mathrm{~cm}$, the diameter with more than $5 \mathrm{~cm}$, the weight with 5 $\mathrm{g}$, plants having in average compared to the spring crops (Laczi and Apahidean 2011, 2012; Laczi et al., 2014b).

One month after planting plants height varied between $15.8 \mathrm{~cm}$, at Vitimo $\mathrm{F}_{1}$ hybrid and 27.5 $\mathrm{cm}$ at hybrid Michihli, the diameter between 32.5 $\mathrm{cm}$ at Vitimo $\mathrm{F}_{1}$ hybrid and $47.8 \mathrm{~cm}$ at Nepa $F_{1}$ hybrid. Hybrid Kingdom 80 had the most leaves (in average 19.5), while at Michihli hybrid there were numbered, in average, only 14.5 leaves (tab. 2). The results from the autumn experiment made in polyethylene tunnel (Laczi et al., 2014) reveals that better environmental conditions from the protected space lead to higher values of plants height, not only a month after planting, but at harvest to. It can be concluded that better growing conditions can assure bigger plants with higher weights and more leaves. In the spring crops, plants heights varied between 18.8 and $41.8 \mathrm{~cm}$, higher values being recorded at the same Michihli hybrid, lower ones at Vitimo $\mathrm{F}_{1}$ hybrid. In spring conditions the number of leaves which were formed in one month was approximately the same as in the present study (Laczi and Apahidean 2011, 2012; Laczi et al., 2014b).

Lowest values of the mature plants were registered at Vitimo $F_{1}$ - the average height of plants was $23.2 \mathrm{~cm}$, the average diameter $44.7 \mathrm{~cm}$ and the average weight of plants was $700 \mathrm{~g}$. Even if the highest plant height $(40.0 \mathrm{~cm})$ and weight $(990$ g) was recorded at Nepa $F_{1}$ hybrid, the most leaves, in average 47.2, were numbered at Kingdom 80 hybrid (tab. 3).

Compared to the results from the spring crops, in this case plants had higher heights, diameters and weights than those cultivated in open field (Laczi and Apahidean, 2011; 2012), but lower

Tab. 1. Development degree of seedlings at planting.

\begin{tabular}{|c|c|c|c|c|c|}
\hline \multicolumn{2}{|r|}{ Variant } & \multirow{2}{*}{$\begin{array}{l}\text { Plant height } \\
(\mathrm{cm})\end{array}$} & \multirow{2}{*}{$\begin{array}{l}\text { Plant diameter } \\
(\mathrm{cm})\end{array}$} & \multirow{2}{*}{ Number of leaves } & \multirow{2}{*}{$\begin{array}{l}\text { Plant weight } \\
\text { (g) }\end{array}$} \\
\hline No. & Variaty / Hybrid & & & & \\
\hline 1 & Michihli & 27.3 & 23.0 & 7.7 & 14.3 \\
\hline 2 & Kingdom 80 & 22.3 & 22.3 & 7.6 & 14.7 \\
\hline 3 & Granat & 22.7 & 21.7 & 8.0 & 17.0 \\
\hline 4 & Nepa $F_{1}$ & 25.8 & 25.7 & 9.3 & 17.7 \\
\hline \multirow[t]{2}{*}{5} & Vitimo $_{1}$ & 18.7 & 26.0 & 7.7 & 14.0 \\
\hline & Average & 23.4 & 23.7 & 8.1 & 15.5 \\
\hline
\end{tabular}

Tab. 2. Development degree of plants one month after planting.

\begin{tabular}{|c|c|c|c|c|}
\hline & Variant & \multirow{2}{*}{$\begin{array}{l}\text { Plant height } \\
\text { (cm) }\end{array}$} & \multirow{2}{*}{$\begin{array}{l}\text { Plant diameter } \\
(\mathrm{cm})\end{array}$} & \multirow{2}{*}{ Number of leaves } \\
\hline No. & Variaty / Hybrid & & & \\
\hline 1 & Michihli & 27.5 & 42.5 & 14.5 \\
\hline 2 & Kingdom 80 & 18.8 & 41.5 & 19.5 \\
\hline 3 & Granat & 20.0 & 42.5 & 17.2 \\
\hline 4 & Nepa $F_{1}$ & 24.8 & 47.8 & 17.8 \\
\hline 5 & Vitimo $\mathrm{F}_{1}$ & 15.8 & 32.5 & 17.7 \\
\hline & Average & 21.4 & 41.4 & 17.3 \\
\hline
\end{tabular}


Tab. 3. Development degree of plants at maturity.

\begin{tabular}{|c|c|c|c|c|c|}
\hline \multicolumn{2}{|r|}{ Variant } & \multicolumn{4}{|c|}{ Plant } \\
\hline No. & Variaty / Hybrid & $\begin{array}{l}\text { Height } \\
\text { (cm) }\end{array}$ & $\begin{array}{l}\text { Diameter } \\
(\mathrm{cm})\end{array}$ & $\begin{array}{c}\text { Total weight } \\
\text { (g) }\end{array}$ & $\begin{array}{c}\text { Number o } \\
\text { leaves }\end{array}$ \\
\hline 1 & Michihli & 38.3 & 62.2 & 670 & 27.3 \\
\hline 2 & Kingdom 80 & 32.3 & 59.3 & 740 & 47.2 \\
\hline 3 & Granat & 38.0 & 53.8 & 880 & 37.3 \\
\hline 4 & Nepa $F_{1}$ & 40.0 & 64.7 & 990 & 38.8 \\
\hline 5 & Vitimo $_{1}$ & 23.2 & 44.7 & 700 & 46.8 \\
\hline & Average & 34.4 & 56.9 & 790 & 39.5 \\
\hline
\end{tabular}

Tab. 4. Development degree of cabbage head at harvest.

\begin{tabular}{|c|c|c|c|c|c|}
\hline \multirow{2}{*}{\multicolumn{2}{|c|}{ Variant }} & \multicolumn{4}{|c|}{ Cabbage head } \\
\hline & & \multirow{2}{*}{$\begin{array}{c}\text { Height } \\
(\mathrm{cm})\end{array}$} & \multirow{2}{*}{$\begin{array}{l}\text { Diameter } \\
(\mathrm{cm})\end{array}$} & \multirow{2}{*}{$\begin{array}{c}\text { Total weight } \\
(\mathrm{g})\end{array}$} & \multirow{2}{*}{$\begin{array}{c}\text { Number of } \\
\text { leaves }\end{array}$} \\
\hline No. & Variaty / Hybrid & & & & \\
\hline 1 & Michihli & 42.0 & 42.3 & 570 & 20.5 \\
\hline 2 & Kingdom 80 & 37.2 & 27.7 & 620 & 40.7 \\
\hline 3 & Granat & 32.8 & 38.7 & 750 & 30.5 \\
\hline 4 & Nepa $F_{1}$ & 37.8 & 47.0 & 860 & 31.0 \\
\hline 5 & Vitimo $\mathrm{F}_{1}$ & 33.2 & 26.8 & 580 & 38.7 \\
\hline & Average & 36.6 & 36.5 & 670 & 32.3 \\
\hline
\end{tabular}

ones than those from the protected crop (Laczi et al., 2014b). In autumn plants had much more leaves than those from the spring crops, fact due to the longer vegetation period and better climatic conditions from fall.

Regarding the cabbage heads (tab. 4), hybrid Michihli presented the longest heads (with an average of $42.0 \mathrm{~cm}$ ), but at the same time the heads with the lowest weight $(0.56 \mathrm{~kg})$ and lowest number of leaves (in average 20.5), result which are in accordance with those found in spring crops (Laczi and Apahidean, 2011; 2012; Laczi et al., $2014 \mathrm{~b})$. Heads with highest diameter $(47.0 \mathrm{~cm})$ and weight $(0.86 \mathrm{~kg})$ were registered at Nepa $\mathrm{F}_{1}$ hybrid, while the most leaves (in average 40.7) were numbered at Kingdom 80 hybrid, followed closely by Vitimo $\mathrm{F}_{1}$, it woth mentioning that in all experiments Kingdom 80 hybrid had the highest number of leaves (Laczi and Apahidean, 2011; 2012; Laczi et al., 2014b). The weights were lower than that found in an experiment made by Sammis et al. (1988) where heads from spring culture, had weights witch ranged between $1.36 \mathrm{~kg}$ to 1.74 $\mathrm{kg}$ when planting was effectuated in April and between $1.21 \mathrm{~kg}$ and $1.41 \mathrm{~kg}$ when planting was realized in March.

After harvest the outer leaves were removed, obtaining the marketable heads. It can be observed that the difference between plants and heads weight varies between 100 and 130 $\mathrm{g}$, the lowest difference being noted at Michihli hybrid. The lower difference between these two characteristics is an important factor, because the smaller the difference, the looses will be smaller too and the marketable production will be higher. An other factor which can leads to high looses is the attack of pests and diseases, which can lead to depreciation of more leaves which have to be eliminated (Tab. 3-4).

Most of the leaves take part in the heads formation, in average more than 32; while the rosettes are formed in average from 7-8 leaves. From the total number of leaves $86.33 \%$ took place in the head formation at Kingdom 80 hybrid and only $75 \%$ at hybrid Michihli (Tab. 3-4). Earlier studies upon a collection of hybrids and varieties of Chinese cabbage showed that in spring culture the leaves number from cabbage heads varied 
between 19.83 and 43.33 (Laczi and Apahidean, 2012). Plants are able to form more leaves, in special if they benefit of better conditions (Laczi et al., 2014).

A distinct significant positive correlation was observed between total weight of the plants and the heads weight (the correlation coefficient having a value of $r=0.99^{* *}$ ) as shown in fig. 1 , so it could be concluded that with the increasing of the plants total weight the cabbage heads are increasing to. Same results were found by Červenski et al. (2010) at cabbage.

The observations made on plants bolting (fig. 2) revealed that one month after planting, at four variants represented by hybrids Kingdom 80, Nepa $\mathrm{F}_{1}$ and Vitimo $\mathrm{F}_{1}$ and at Granat variety, there were no bolted plants, while at Michihli hybrid the bolting percentage had already a value of $29.17 \%$. At harvest only Vitimo $F_{1}$ hybrid presented a minimum bolting percentage, while at Michihli hybrid the percentage passed $40 \%$. The average bolting percentage was $5.83 \%$ at one month after planting and $17.50 \%$ at harvest. Studies showed that a lower number of plant will bolt if the culture is established in protected spaces (Laczi et al., 2013; Laczi and Apahidean, 2012; Laczi et al., 2014a).
The yield (tab. 5) obtained within this experiment varied between $45.33 \mathrm{t} / \mathrm{ha}$ at Michihli hybrid and $67.21 \%$ at hybrid Nepa $\mathrm{F}_{1}$. Compared to results obtained at Granat variety, the control variant of the experiment, which realized a yield of 60.23 t/ha, Nepa $F_{1}$ hybrid, with a higher yield, obtained a distinct significant positive difference, while hybrids Kingdom 80, Michihli and Vitimo $\mathrm{F}_{1}$, with lower yields significant negative differences.

Compared the variants yields to the average yield (53.78 t/ha) a very significant positive difference was recorded at Nepa $\mathrm{F}_{1}$ hybrid (with a yield increasing of $25 \%$ ), a distinct significant positive at Granat variety (with a yield increasing of $12 \%$ ), a significant negative difference at Kingdom 80 hybrid (with a yield decreasing of $8 \%$ ) and two very significant negative differences, at Michihli and Vitimo $\mathrm{F}_{1}$ hybrids (with yield decreasing of $15.7 \%$, respectively $13.2 \%$ ).

Even if the plants had better conditions in protected space in the same period, in the study of Laczi et al. (2014a), the average yield was lower (52.53 t/ha); the highest production being registered at Granat variety (62.93 t/ha). Lower average yield (49.44 t/ha) was registered in late spring conditions to (Laczi et al, 2014b), while in spring protected culture the yield was significantly

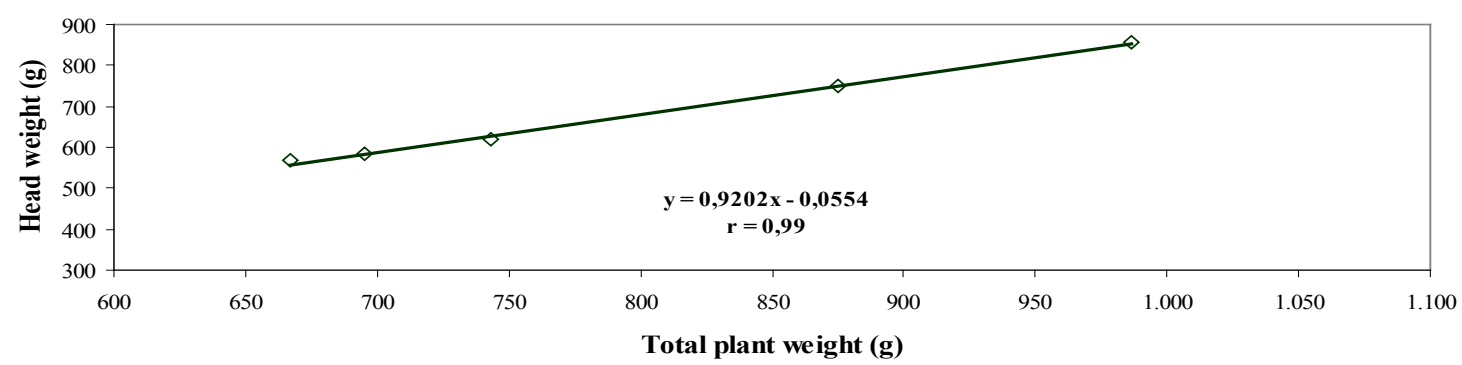

Fig. 1. Relationship between total plant weight and head weight $(n=5, p(5 \%)=0.88, p(1 \%)=0.96)$.

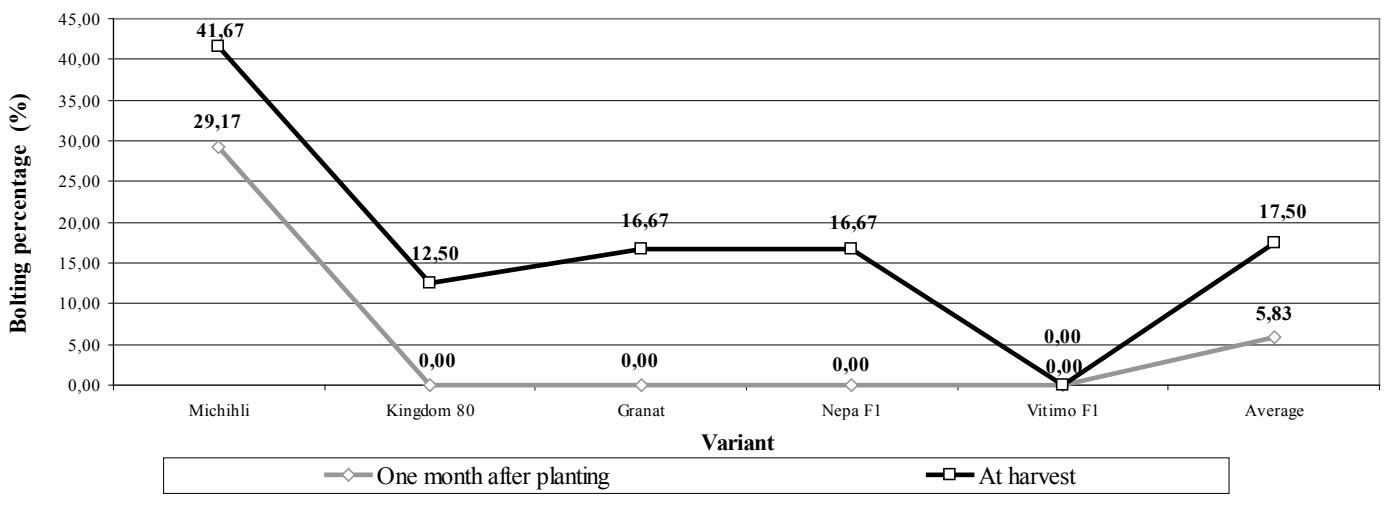

Fig. 2. Bolting percentage. 
Tab. 5. Unilateral influence of the cultivar upon the Chinese cabbage yield.

\begin{tabular}{cccccccc}
\hline Variaty / & $\begin{array}{c}\text { Average } \\
\text { yield } \\
\text { Hybrid }\end{array}$ & $\begin{array}{c}\text { Relative } \\
\text { yield } \\
(\%)\end{array}$ & $\begin{array}{c}\text { Difference } \\
(\mathrm{t} / \mathrm{ha})\end{array}$ & Significance & $\begin{array}{c}\text { Relative } \\
\text { yield } \\
(\%)\end{array}$ & $\begin{array}{c}\text { Difference } \\
\text { (t/ha) }\end{array}$ & Significance \\
\hline Granat & 60.23 & 100.0 & 0.00 & Mt. & 112.0 & 6.45 & $* *$ \\
Kingdom 80 & 49.47 & 78.2 & -10.76 & ooo & 92.0 & -4.31 & o \\
Michihli & 45.33 & 75.3 & -14.9 & ooo & 84.3 & -8.45 & ooo \\
Nepa F & 67.21 & 11.6 & 6.98 & $* *$ & 125.0 & 13.43 & $* * *$ \\
Vitimo $F_{1}$ & 46.67 & 77.5 & -13.56 & ooo & 86.8 & -7.11 & ooo \\
\hline Average & 53.78 & - & - & - & 100.0 & 0.00 & Mt. \\
\hline \multicolumn{2}{l}{ LSD (p 5\%) } & & & 3.06 & & & 3.06 \\
LSD (p 1\%) & & & 4.45 & & & 4.45 \\
LSD (p 0.1\%) & & & 7.03 & & & 7.03 \\
\hline
\end{tabular}

Tab. 6. The influence of the cultivar upon the Chinese cabbage yield (Duncan test).

\begin{tabular}{ccc}
\hline Variaty / Hybrid & $\begin{array}{c}\text { Average yield } \\
\text { (t/ha) }\end{array}$ & Significance \\
\hline Granat & 60.23 & $\mathrm{C}$ \\
Kingdom 80 & 49.47 & $\mathrm{~B}$ \\
Michihli & 45.33 & $\mathrm{~A}$ \\
Nepa F $_{1}$ & 67.21 & $\mathrm{C}$ \\
Vitimo F $_{1}$ & 46.67 & $\mathrm{~A}$ \\
\hline
\end{tabular}

Note: Different letters between hybrids denote significant differences (Duncan test, $\mathrm{p}<0.05$ ).

higher (85.63 t/ha) (Laczi and Apahidean, 2012). Highest yields were registered at Kingdom 80 hybrid in first case and Vitimo $\mathrm{F}_{1}$ in the second one. Yield up to $57.1 \mathrm{t} / \mathrm{ha}$ found Sammis et al. (1988) in their experiment when planting was made in March, while with the delaying of the planting until April the yields increased up to 63.2 t/ha.

Between the yields registered at Michihli and Vitimo $F_{1}$ there was no statistically supported difference, while between this two and all the other hybrids the difference was significant according to Duncan test (tab. 6).

\section{CONCLUSIONS AND RECOMMENDATIONS}

Even if Chinese cabbage is not a traditionally vegetable in Transylvanian Tableland studies have shown that it can be cultivated with great results. The present research has demonstrated that yields up to $67 \mathrm{t} /$ ha can be obtain even in autumn crops. The success of the Chinese cabbage crop is in direct relationship with the choosing of a good hybrid, which is bolting resistant and can give a high yield. Taking into consideration the result of this variety trial, Vitimo $\mathrm{F}_{1}$ hybrid can be recommended for cultivation, because its resistance to premature flowering. Nepa $F_{1}$ hybrid is recommended when a high yield is pursued, but harvesting have to be made when the first heads show signs of bolting, in this way avoiding looses caused by early flowering. Michihli hybrid is recommended not to be taken into culture in this period of the year because of its high tendency to bolt.

Acknowledgments. This paper was published under the frame of European Social Fund, HumanResources Development Operational Programme 2007-2013, project no. POSDRU/159/1.5/S/132765.

\section{REFERENCES}

1. Chaux C, Foury C (1994). Production légumières. TECDOC, Paris, 45-56.

2. Červenski J, Gvozdanović-Varga J, Vasić M, Glogovac S (2010). Multivariate analysis for head weight and yield performance of experimental cabbage hybrids (Brassica oleracea var. capitata L.). GENETIKA, 42 (2) 259-266

3. Kalisz A, Cebula S (2006). The effect of temperature on growth and chemical composition of Chinese cabbage seedlings in spring period. Folia Horticulturae 18/1: 3-15

4. Kawashima LM, Valentesolares LM (2003), Mineral profile of raw and cooked leafy vegetables consumed in Southern Brazil. Journal of Food Composition and Analysis. 16: 605611.

5. Laczi E, Apahidean AS (2011): Research regarding the introduction of a least known vegetable species in culture, in Transylvanian tableland area; the possibility of cultivating Chinese cabbage in early spring in open field. Journal Plant development 18: 33-40. 
6. Laczi E, Apahidean AS (2012): Protected culture study of Chinese cabbage (Brassica campestris var pekinensis) varieties and hybrids collection grown in the Transylvanian Tableland specific conditions. Brukenthal. Acta Musei VII. 3:579-588.

7. Laczi E, Apahidean AS, Dumitraș A, Boancă P, Apahidean AI, Tomoş C (2013). Growing Chinese Cabbage: Indoor or Outdoor?. Bulletin UASVM Horticulture 70(1): 251-252.

8. Laczi E, Apahidean A, Luca E, Dumitraș A, Boancă P (2014a). The growth, development and yield of headed Chinese cabbage in autumn protected culture in Transylvanian Tableland specific conditions. Agriculture - Science and Practice 1- 2(89-90): 85-89.

9. Laczi E, Apahidean A, Luca E, Dumitraș A, Boancă P (2014b). Late spring culture of headed Chinese cabbage (Brassica campestris var. pekinensis), The 13th International Symposium Prospects for the 3rd Millenium Agriculture, 25th-27th September, Cluj Napoca, Romania
10. Larkcom J (2003). The Organic Salad Garden. Frances Lincoln Limited, London: 31-33.

11. Larkcom J. (2008). Oriental vegetables. - Kodansha International Ltd. Tokyo: 17-30

12. Morariu T, Savu A (1970). Judetele patriei-Judetul Cluj, Ed. Acad. R.S. Romania, Bucuresti.

13. Pokluda R (2008). Nutritional quality of Chinese cabbage from integrated culture, Hort. Sci., 35: 145-150.

14. Sammis TW, Kratky BA, Wu IP (1988). Effects of limited irrigation on lettuce and Chinese cabbage yields. Irrig. Sci. 9: $187-198$

15. Toxopeus H, Baas J (2004). Ressources végétales de l'Afrique tropicale 2. Fundation Prota / Backhuys Publishers / CTA. Wageningen. 162-169.

16. Fresh Chinese cabbages specification (2012). The African Organization for Standardisation 